\title{
MÉLTÁNYOSSÁG VAGY RACIONALITÁS? A TÚLZOTT KOMPENZÁCIÓ HATÁSA
}

\begin{abstract}
A szolgáltatói panaszkezelés egyik legfontosabb eszköze a fogyasztó kompenzálása. A szolgáltatóvállalatok gyakori stratégiája, hogy az okozott kárnál jóval magasabb összegű kompenzációt ajánlanak fel, ezt nevezzük túlkompenzációnak. A szakirodalomban igen ellentmondásos eredmények találhatók azzal kapcsolatban, hogy e túlzott kompenzációs összeg pozitívan vagy negatívan befolyásolja-e a károsult ügyfelek panaszhelyzet utáni magatartását. A szerzők kutatásának célja, hogy egy további tényező, a fogyasztói többlet-erőfeszítés bevonásával magyarázatot adjanak ezen ellentmondások egy lehetséges okára. Mélyinterjúk segítségével először azonosították a fogyasztói többlet-erőfeszítés és a szolgáltatás újrateljesítésén felüli további kompenzációs elvárások közötti kapcsolatot, majd kísérleti módszertan segítségével megvizsgálták a túlzott kártérítési összeg elégedettségre és észlelt panaszkezelési igazságosságra gyakorolt hatását. A kutatási eredmények alapján világossá vált, hogy a kártérítés összege és formája, valamint a fogyasztók részéről kifejtendő többleterőfeszítés mértéke mind az elégedettségre, mind pedig az észlelt panaszkezelési igazságosságra hatást gyakorol.
\end{abstract}

Kulcsszavak: kompenzáció, fogyasztói magatartás, panaszkezelés, elégedettség, igazságosság

A szolgáltatóvállalatok tevékenységük során bizonyos helyzetekben hibákat vétenek, melyből adódóan fogyasztói veszteség keletkezik. E károk következtében az ügyfelek elégedetlenek lesznek a szolgáltató teljesítményével, és panaszhelyzet alakulhat ki. Az elégedetlen fogyasztók megtartásának egyik kulcsát a megfelelö panaszkezelési eljárás kialakítása jelenti, mely révén a hibáért felelős vállalat képes arra, hogy a fogyasztók elégedetlenségét elégedettséggé alakítsa át. A panaszkezelési eljáráson belül kritikus pont a kártérítés összegének meghatározása.

A szolgáltatóvállalatoknak többféle lehetőségük van a panaszhelyzetből következő kár helyreállítására. Az egyik ilyen lehetőség a fogyasztó kárát meghaladó összegü kártérítés felajánlása, a túlkompenzáció. A vállalatok szempontjából igen fontos annak megértése, hogy a károsult ügyfelek milyen helyzetekben várják el a szolgáltatási hiba kijavításán túlmutató kártérítés felajánlását, valamint ennek milyen hatása van a fogyasztók panaszkezelés utáni magatartására. Noha első hallásra evidensnek tünhet, hogy a fogyasztó számára a felajánlott kártérítés összegével arányosan növekszik elégedettsége, az igazságosság elmélete alapján ez nem feltétlenül igaz. Ez az ellentmondás a korábbi kutatási eredmények elemzése során is láthatóvá válik, hiszen egymásnak sokszor ellentmondó eredmények születtek. Egyes kutatók arra jutottak, hogy a túlzott kompenzáció segíthet a vevői elégedettség visszaszerzésében, míg mások szerint a vevő igazságosságérzete sérül, így végső soron nem lesz elégedett a panaszkezeléssel (Noone \& Lee, 2012; Noone, 2011; Crisafulli \& Singh, 2016; Haesevoets et al., 2014; Haesevoets et al., 2017).

Kutatásunk célja, hogy feltárjuk ezen ellentmondó eredmények mögött húzódó tényezőket, kialakítsunk és teszteljünk egy olyan elméleti keretet, amely magyarázhatja a túlzott kompenzációra adott eltérő fogyasztói reakciókat. Kutatásunk központi kérdése, hogy a fogyasztói erőfeszítés, amelyet a helyreállítás érdekében kell tennie, mennyiben határozza meg elégedettségét. Kutatásunk központi kérdése mellett arra is szeretnénk választ kapni, hogy vajon az anyagi kompenzáció formája befolyásolja-e a panaszkezeléssel való elégedettséget.

Cikkünkben először bemutatjuk az anyagi kompenzáció hatására vonatkozó eddigi kutatásokat, az igazságosság elméleti keretét felhasználva. Kitérünk azokra a szempontokra, amelyek befolyásolhatják a kompenzáció különböző formáival való elégedettséget, majd összevetjük a túlzott kompenzáció hatásának eddigi kutatási eredményeit. A cikk második részében bemutatjuk kutatási modellünket, amelyet előzetes kvalitatív interjúk alapján alakítottunk ki. Hipotéziseink tesztelésére szcenárióalapú kísérleti módszertant alkalmaztunk, ennek részletes bemutatása és az eredmények ismertetése után cikkünk befejezéseként a szolgáltatóvállalatok számára levonható legfontosabb következtetésekre is kitérünk.

\section{Elméleti háttér}

Annak érdekében, hogy egy vállalat a panaszhelyzet során kialakult elégedetlenséget elégedettséggé alakítsa át, professzionális panaszkezelési eljárás kialakítására van szüksége, mely eredményeképpen pozitív fogyasztói hozzáállás alakítható ki. Amennyiben a károsult fogyasztókat nem kompenzálja megfelelő mértékben a vállalat, akkor valószínủleg elégedetlenek lesznek, és nem lesznek hajlandók ismét igénybe venni a szolgáltató által felajánlott szolgáltatást. Ezen túl, egy nem megfelelően kompenzált ügyfél a negatív tapasztalatainak hangoztatása révén számos potenciális fogyasztót meggyőzhet arról, hogy a vállalat szolgáltatása rossz minőségü, mely révén a vállalat eleshet e fogyasztók kiadásaiból származó profittól is.

A panaszkezelés kutatása során leggyakrabban alkalmazott elméleti háttér az igazságosság elméleti kerete, amely három szempontból vizsgálja meg, hogy a fogyasztó számára mennyire lehet megfelelő a panaszkezelési eljárás. 


\section{Az igazságosság elmélete a panaszkezelésben}

A vásárlók a szolgáltatási folyamat során bekövetkezett hibából eredő korrekció méltányosságát a kapott kompenzáció, a panaszkezelés folyamata és az alkalmazottak fogyasztóval szembeni bánásmódja szerint ítélik meg. Ez alapján elmondható, hogy a panaszkezelési kontextusban az igazságosság három dimenzióját különíthetjük el egymástól: beszélhetünk kompenzációs, procedurális és interakciós igazságosságról. A procedurális igazságosságot a helyreállítási folyamaton belüli eljárások és események méltányossága határozza meg, az interakciós igazságosság a panaszkezelési folyamat során megfigyelhetö kommunikációval és alkalmazotti viselkedésformával van öszszefüggésben, míg a kompenzációs igazságosság a kapott kárpótolás észlelt méltányosságának függvénye. Utóbbi dimenzió szerint a károsult fogyasztó a veszteségeket és a bevételeket hasonlítja össze egymással a tranzakció igazságosságának meghatározása érdekében. Amennyiben a veszteségek és bevételek összehasonlítása során a fogyasztók egyenlőséget tapasztalnak, akkor a köztük és a vállalat között kialakult kapcsolatot igazságosnak fogják tekinteni, míg nem megfelelő arány esetén igazságtalanságot fognak észlelni (Blodgett et al., 1997; Kenesei \& Kolos, 2008). Manna és Chaudhry (2013) szerzőpáros szerint egy szolgáltatási hibát sok esetben lehetetlen kijavítani, így ezen esetekben az empátia és az udvariasság kulcsfontosságú tényező a károsult fél elkötelezettségének, lojalitásának kialakításában. Az interakciós igazságosság az elosztás igazságosságának alacsonyabb szintjeinek ellensúlyozására is szolgál. A háromtípusú igazságosság egymással sok esetben kiegészíthető is. Bizonyos helyzetekben a megfelelő interakciós és procedurális igazságosság kiválthatja a kompenzációs igazságosságot (Wirtz \& Mattila, 2004).

Az igazságosság észlelését leginkább három tényezö: az egyenlöség, a méltányosság és a szükséglet határozza meg (Davidow, 2003).

- Az egyenlöség elve a felek által elnyert végkimenetek egyenlőségének fontosságát hangsúlyozza. Az egyenlőség elve szerint akkor méltányos egy panaszkezelési folyamat, ha az azonos hibát tapasztaló fogyasztók megegyező panaszkezelést tapasztalnak.

- A szükséglet elve a felek egyéni szükségleteinek kielégítésével van összefüggésben. Davidow (2003) erre a szabad helyek hiányának példáját hozza egy repülőgép esetén. Eszerint a szabad ülést az a fogyasztó kapja meg, akinek a legnagyobb a szüksége arra, hogy eljusson az úti célba.

- A kompenzációs igazságosság vizsgálata során fontos szerepet kap a méltányossági elv is. A méltányosság azt jelenti, hogy az ügyfelek akkor éreznek méltányosnak egy folyamatot, ha az olyan veszteségek, mint például a panasz benyújtásának időigényessége, vagy a szükséges erőfeszítések nem nagyobbak, mint a helyreállítási folyamat során megszerzett nyereségek (például a visszatérítés vagy a kedvezmény) (Roschk \& Gelbrich, 2014; Crisafulli \& Singh, 2016; Blodgett et al., 1997).
Jelen kutatás a kompenzációs igazságosság vizsgálatára helyezi a hangsúlyt a túlkompenzáció fogyasztói magatartásra gyakorolt hatásainak elemzése révén.

\section{A kompenzáció szerepe}

A kompenzációt úgy határozhatjuk meg, mint a vállalatok által az elégedetlen ügyfelek számára nyújtott kézzelfogható jogorvoslatot (Gelbrich et al., 2015). A megfelelő formájú és mértékủ kártérítés fontosságára Standop és Grunwald (2009) kutatása hívja fel a figyelmet, amely során a kompenzáció és az elégedettség kapcsolatát vizsgálva arra jutottak, hogy a szolgáltatási hiba sikeres kiküszöbölése nagyobb elégedettséghez vezethet, mint amikor az ügyfélnek nincs negatív tapasztalata az adott szolgáltatással vagy szolgáltatóval kapcsolatban. Az elégedetlen fogyasztók negatív hozzáállásának megváltoztatásához tehát a szolgáltatási hiba kijavítására van szükség. Annak érdekében, hogy a vállalatok kárpótolják az elégedetlen ügyfeleket az elszenvedett anyagi és nem anyagi jellegü veszteségekért, kompenzációt juttatnak számukra (Blodgett et al., 1997; Gelbrich \& Rroschk, 2011). Egy szolgáltatási hibát a kompenzáció két fajtájával ellensúlyozhatjuk: a megfogható (anyagi) és megfoghatatlan (pszichológiai) kompenzációval, melyek közül előbbi kategóriába a pénzben kifejezhetö kártérítést sorolhatjuk, utóbbiba pedig az olyan megfoghatatlan kompenzációt, mely érzelmi kompenzációt nyújt a károsult fél számára (Roschk \& Gelbrich, 2014). Kézzelfogható kompenzáció lehet pénzvisszafizetés, egy utalvány, kupon, vagy a fogyasztó számára felajánlott termékcsere, vagy a szolgáltatás újbóli végrehajtása, míg a megfoghatatlan, vagy pszichológiai kompenzációt az empatikus megértés és az őszinte bocsánatkérés képviselheti (Gelbrich \& Roschk, 2011; Gelbrich et al., 2016). A megfoghatatlan kártérités fontosságát jól reprezentálja a nem megfelelő bánásmód következtében kialakult panaszhelyzet, mely során a fogyasztót érzelmi veszteség éri, így a pszichológiai kompenzációnak is jelentős szerepe van. A kompenzáció e formája hozzájárul a károsult fél önbecsülésének megőrzéséhez és a fogyasztókkal való hosszú távú kapcsolat kialakításához (Standop \& Grunwald, 2009; Roschk \& Gelbrich, 2014).

\section{Az anyagi kompenzáció eltérő szintjeinek bemutatása}

A szolgáltatási hiba során realizált fogyasztói veszteségek ellensúlyozására szolgáló kompenzáció mértéke nem minden esetben van összhangban az elégedetlen ügyfél hiba kapcsán felmerülő költségeivel. A kompenzáció megfelelő mértékét több tényező is befolyásolja. Az ügyfél elözetes tapasztalatai, a vállalati kommunikáció, a többi fogyasztó által elért kompenzáció és az ügyfélnek okozott kár mértéke is hatással van a kompenzáció elfogadható szintjére (Kenesei et al., 2017). Az ügyfélnek okozott kár következtében a károsult vásárlók veszteséget realizálnak, mely veszteség mértéke egyenes arányban van az elvárt kompenzációs összeg nagyságával, így a panaszosok számára legalább a szolgáltatási hibát megelőző állapotot kell visszaállítani, máskülönben elégedetlen fogyasztókkal találhatjuk szembe magunkat. Összességében tehát elmondható, hogy minél nagyobb a fogyasztóknak okozott vesz- 
teség, annál nagyobb kompenzációt követelnek a vásárlók a hiba következtében fellépő veszteségek ellensúlyozása érdekében (Kim \& Ulgado, 2012; Davidow, 2003). A kompenzációt általában a fogyasztók veszteségének százalékában határozzák meg, így beszélhetünk részleges, teljes vagy túlkompenzációról (Gelbrich et al., 2015):

- A részleges kompenzáció esetében a szolgáltató a vevői veszteség egy részét téríti meg. Ilyen eset olyankor szokott előfordulni, amikor a vevő már igénybe vette a szolgáltatást, mégis végeredményben elégedetlen a szolgáltatás egyik összetevőjével. A vasúttársaság például a jelentősebb késés esetén a jegy árának csak egy részét téríti vissza, nem pedig az egész összeget, noha a szolgáltatás az eredetileg vállalt feltételek szerint nem teljesült.

- A teljes kompenzáció a veszteséggel megegyező összegű kompenzációt jelenti. A teljes kompenzáció révén a vállalatoknak lehetőségük nyílik a hibát megelőző helyzet helyreállítására. Előfordulhat azonban az is, hogy a vállalat nem nyújt kárpótlást a fogyasztókat ért minden veszteségért (Gelbrich et al., 2015; Gelbrich \& Roschk, 2011). A fogyasztók nem biztos, hogy akkor éreznek egy tranzakciót egyenlőnek, ha a teljes vételárat visszanyerik, mivel a hiba során lehet, hogy más költségeik is felmerülnek. Ebből a szempontból tehát a vevő lehetséges, hogy nem tekinti valódi teljes kompenzációnak azt az esetet, amikor a vállalat ugyan visszafizeti a szolgáltatás vételárát, de a vevő egyéb felmerült költségeit nem fizeti ki. Ilyen eset lehet, ha a repülögépet törlik, és visszaadják ugyan a jegy teljes árát, de az elveszett szállásdíjat már nem fizetik ki, noha lehetséges, hogy a törölt gép miatt az utas nem érkezik meg idejében, hogy elfoglalhassa kifizetett szállodai szobáját. Másrészről a panasz megtételéért a fogyasztónak gyakran újra fel kell keresnie a vállalatot, mely további pénzügyi és pszichológiai költségeket is maga után von. Épp emiatt, annak érdekében, hogy a hiba bekövetkezését megelőző helyzetet visszaállítsák a vételárnál magasabb összegü kompenzáció biztosítása szükséges (Haesevoets et al., 2017).

- A kompenzációnak ezt a kategóriáját a túlkompenzáció képviseli, mely a vételáron felül nyújtott további kompenzációt takarja, amelyet a szolgáltatási kudarc következtében fellépő fogyasztói veszteség kompenzálása érdekében nyújtanak a szolgáltatóvállalatok az elégedetlen fogyasztók számára. A túlkompenzáció tehát a fogyasztói közvetlen veszteséget, azaz az egyszerü kompenzációt meghaladó összeget biztosítja (Haesevoets et al,. 2017; Noone \& Lee, 2011; Noone, 2012; Crisafulli \& Singh, 2016).

A túlkompenzációról az egyenlő kompenzációhoz viszonyítva elmondható, hogy a szolgáltatóvállalat oldaláról nézve költségesebb megoldás, hiszen a teljes kompenzációt meghaladó mértékủ kártérítést nyújt a károsult ügyfél számára, míg fogyasztói oldalról jövedelmezöbb a magasabb összegü kompenzáció. Vállalatok törekszenek arra, hogy minél alacsonyabban tartsák a szolgáltatás helyreállításából eredő költségeiket, így amíg a túlkompenzáció előnyei nem haladják meg jelentős mértékben a részleges vagy tel- jes kompenzációból származó előnyöket, addig a túlkompenzáció helyett érdemesebb az alacsonyabb költségekkel járó kompenzációs formákat választani (Noone, 2012).

\section{A túlkompenzáció pszichológiai és gazdasági oldalról történő megközelítése}

Míg a kártérítést megelőzően az ügyfél elönytelen egyenlőtlenséget érzett a felmerült hiba következtében, addig a túlkompenzációt követően egyenlőség helyett „előnyös egyenlőtlenség” érzése alakul ki az ügyfelekben (Haesevoets et al., 2014). A méltányossággal kapcsolatos kutatások rámutattak, hogy az emberek a pozitív egyenlőtlenséget preferálják a negatív egyenlőtlenséggel szemben, míg a pozitív egyenlőtlenséget kialakító kompenzáció előnyben részesítése az egyenlő helyzetet teremtő kártérítéssel szemben már nem ennyire egyértelmü (Garrett, 1999). Az egyes kompenzációs összegek fogyasztók általi értékelésének különbözőségeire a pszichológiai és a gazdasági perspektíva adhat magyarázatot.

- A pszichológiai megközelítés szerint a károsult félnek nem csupán a kapott kompenzáció nagysága, hanem azok tisztességessége és a veszteségekkel való megfelelő aránya is hatással van a későbbi fogyasztói magatartásra. Épp ezért, az egyenlőtlen helyzetet kialakító kompenzációkkal szemben a fogyasztók inkább az egyenlő kompenzációhoz ragaszkodnak, így ezt a típusú kompenzációt jobbnak értékelik a túlkompenzációhoz képest, mindannak ellenére, hogy a túlkompenzáció az egyszerü kompenzációval szemben nagyobb nyereséget biztosít számukra (Crisafulli \& Singh, 2016). Crisafulli és Singh (2016) szerint erre az ellentmondásra a pozitív igazságtalanság által kiváltott fogyasztói büntudat adhat magyarázatot.

Bizonyos kutatások épp a pszichológiai megközelítésben állított tények ellenkezőjéről számoltak be. E tanulmányok szerint az ügyfelek nagyobb elégedettséget mutatnak a pozitív egyenlötlenséget kialakító kompenzációt követően, mint amilyen elégedettségi szintet a méltányos kompenzáció segítségével érhetünk el. Így ez alapján a kompenzáció szintjének emelkedése a fogyasztók növekvő elégedettségét vonja maga után (Garrett, 1999).

- Ezt a lehetőséget támasztja alá a gazdasági perspektiva, mely szerint az embereket elsösorban a pénz és a profit hajtja, mely a végkimenetek maximalizálásának fontosságára utal. Eszerint a túlkompenzáció jobb végkimenetelt eredményez, mint az egyenlő kompenzáció, mely révén nagyobb elégedettséget, magasabb újravásárlási hajlandóságot, jobb vállalati megítélést és nagyobb bizalmat érhetünk el (Haesevoets et al., 2014; Haesevoets et al., 2017).

\section{A kompenzáció formái}

A kompenzáció mértéke mellett annak típusa is meghatározó szerepű a fogyasztók panaszkezeléssel kapcsolatos elégedettségét tekintve. Anyagi kompenzációt a vásárlás időpontjában, valamint késleltetett módon is lehet nyújtani az elégedetlen fogyasztók számára. Ez alapján különbséget tehetünk készpénzalapú és kuponjellegü túlkompenzáció között. A készpénzalapú kompenzációt jól illusztrálhatja a készpénz visszafizetése, míg kuponjellegű túlkompenzáci- 
óról a következő vásárláskor kedvezményre jogosító kupon esetén beszélhetünk. E két típusú túlkompenzáció mind rugalmasságban, mind időzítésben, mind pedig bizonyosságban eltér egymástól (Roschk \& Gelbrich, 2014; Noone \& Lee, 2012; Noone, 2011; Crisafulli \& Singh, 2016).

- Az idözités a kompenzációhoz kapcsolódó előnyök megszerzésének idejét takarja. A készpénzalapú kompenzáció esetén az ügyfelek azonnal kézhez kapják a szolgáltatási kudarc következtében megszerzett kártérítést, míg a kuponjellegü kompenzáció csak egy későbbi időpontban biztosítja az előnyök megszerzését, amikor a fogyasztó az újbóli vásárlás mellett dönt. Az időzítést vizsgálva elmondható, hogy az ügyfelek a panaszkezelés során azonnal megszerzett előnyöket preferálják a későbbiekben felhasználható előnyökkel szemben.

- A második tényező, mely a készpénz- és a kuponalapú kompenzáció között különbséget tesz, az a bizonytalanságfaktor. Az emberek a készpénzalapú kompenzáció esetén biztosak lehetnek abban, hogy a kártérítést valóban megkapják, hiszen azt azonnal a rendelkezésükre bocsátják, ellentétben a kuponjellegüvel. Az emberek inkább preferálják azt a típusú a kompenzációt, amelyek megszerzésében biztosak, szemben a jövőben várható kártérítéssel.

- A flexibilitás szintén fontos különbség a két típusú kompenzáció között. A készpénzalapú kompenzáció felhasználási lehetőségei sokkal szélesebb körüek, mint a kuponjellegüé, hiszen az ügyfél dönti el, hogy miként szeretné felhasználni a kapott pénzt.

Crisafulli és Singh (2016), valamint Noone és Lee (2011) kutatásukban arra a következtetésre jutottak, hogy az ügyfelek inkább a készpénzalapú túlkompenzációt preferálják a veszteségeik kárpótlásául a kuponjellegűvel szemben. Ezen állítás mellett szól az előbbiekben felsorakoztatott elönyök és hátrányok összessége is, melyek mind a készpénzalapú túlkompenzáció mellett érvelnek. Mindemellett azonban fontosnak tartjuk felhívni a figyelmet a kuponjellegű kompenzáció újravásárlási hajlandóságra gyakorolt pozitív hatására, ugyanis Noone és Lee (2011) kutatása szerint a kuponalapú kompenzációnak van a legerősebb hatása az újravásárlás valószínűségének növelésére. Ez azzal magyarázható, hogy a fogyasztók igyekeznek kihasználni a kuponjellegü kompenzáció nyújtotta lehetőséget, mivel segítségével helyreállíthatják a méltányosságot, így a kupon beváltásához fognak folyamodni a szolgáltatási hibából eredő veszteségek kiegyenlítése érdekében (Noone \& Lee, 2011). Ez egyben egy második lehetőséget is biztosít a vállalatnak arra, hogy bizonyítsa szolgáltatásának minőségi színvonalát, és elégedetté tegye a vevőt.

\section{Primer kutatás}

\section{Feltáró kutatás}

A szakirodalomban fellelhető kutatási eredmények ellentmondásossága ismeretében feltételezhető, hogy léteznek olyan egyéb tényezők, amelyek vizsgálatát be kell építeni a túlkompenzáció elégedettségre gyakorolt hatásának vizsgálatába. Feltáró kutatásunk célja egy olyan tényező meghatározása volt, amely hatással lehet arra, hogy mi- ként reagálnak a fogyasztók a túlzóan magas kompenzációs összegekre. A feltáró kutatás elvégzéséhez a mélyinterjú módszerét használtuk. Az interjúk során két fő téma köré rendeztük a kérdéseinket. Az első részben feltártuk az újrateljesíthető hibás szolgáltatás esetén az alanyok elvárásait az anyagi kompenzációra vonatkozóan, míg a második részben konkrét szituációkat bemutatva kértük meg őket, hogy válaszoljanak arra, hogy mi befolyásolja a kártérítési igényük nagyságát. Ez utóbbi részben már előzetesen szerettünk volna arra is választ kapni, hogy mely szituációkat tartják valóságosnak, mit lenne érdemes egy kvantitatív kutatásban alkalmazni.

Mélyinterjús kutatás során 10 alanyt kérdeztünk meg a szolgáltatói hiba során felmerült kártérítési igényükkel kapcsolatban: 7 nö, valamint 3 férfi vett részt a mélyinterjúk lebonyolításában, életkoruk 23 és 57 év között volt. Mintavétel során törekedtünk a grounded theory-ra jellemző teoretikus mintavételre, mely az elmélet hiányosságainak felfedezésére és pótlására irányul. Az interjúk során nyert adatok kódolásakor a módszer által javasolt kódolási rendszerhez ragaszkodtunk (Charmaz, 2000). Ennek első lépéseként, a nyílt kódolás során a mélyinterjúkban megfigyelhető kulcsszavak és kulcskifejezések identifikálására került sor, mely kulcskifejezéseket esetünkben az olyan szavak jelentették, mint például a „pénzembe került”, „,kellemetlen érzés”, ,elveszi az idömet”, ,,azonnal megcsinálják”, ,illene kompenzálniuk”, a „,nagy erőfeszitésembe kerül" vagy a ,jelentéktelen".

A kódolás következő lépését - axiális kódolás - a kulcskifejezések osztályozása testesíti meg, mely révén olyan kategóriákat hoztunk létre, mint például az „,időköltség”, „,érzelmi költség”, ,,kompenzáció”, ,jelentös többlet-eröfeszités”, vagy a ,jelentéktelen többlet-erőfeszités”. Ezt követően - a kódolás utolsó lépéseként, mely a szelektív kódolás névvel azonosítható - az elmélet alapját jelentő kategóriák kialakítására helyeztük a hangsúlyt, mely lépésben kialakítottuk az „eröfeszités” és a „kompenzáció” kategóriáját. Amikor e kulcsszavak, kategóriák már gyakran ismétlődtek, akkor azt a telítődés jelének tekintettük, így ezt követően nem végeztünk további adatfelvételt.

Az elemzés első fontos eredménye, hogy a vevők alapvetően nem kárpótlást várnak el, hanem azt, hogy a szolgáltató végrehajtsa a szolgáltatást, amiért fizettek. Az interjúk során nyilvánvalóvá vált, hogy a megkérdezettek számára nemcsak a szolgáltatási hiba által okozott konkrét anyagi kár a mérvadó a kárpótlási igényük meghatározásában, hanem az is, hogy a hiba kijavítása milyen egyéb erőfeszítéseket kíván meg tőlük. Az igénybevétel megtörténte Roschk és Gelbrich (2014) kutatásában is felmerült szempontként, ahol arra a megállapításra jutottak, hogy azokban az esetekben van különösen nehéz helyzetben a fogyasztó, ahol már igénybe vette a szolgáltatást, és arra vonatkozóan kellene valamilyen benchmarkot kialakítania a kártérítési igényére vonatkozóan. Kutatásunkban ez a szempont kiegészült az újrateljesíthetőség kérdéskörével. Amennyiben a szolgáltatás újrateljesíthetö, interjúalanyaink egyértelmüen arra utaltak, hogy számukra a jó szolgáltatás a fontos, nem a kártérítés.

E kérdéskör további vizsgálata arra enged következtetni, hogy a hiba kijavítása során a fogyasztótól elvárt több- 
let-erőfeszítés van hatással a kompenzációval kapcsolatos elvárásokra: amennyiben a hiba kijavítása jelentős - akár időbeli, akár pénzügyi, akár érzelmi - plusz költséget igényel, abban az esetben a legtöbb fogyasztó megérdemeltnek vagy elvárhatónak tartja a konkrét gazdasági káron felüli (túl)kompenzálást, szemben azzal, amikor mindenféle erőfeszítés nélkül juthatnak hozzá a kijavított szolgáltatáshoz. Ilyen többlet-erőfeszítés alatt kutatásunkban az olyan, a fogyasztók részéről kifejtendő erőfeszítéseket értünk, mint a hiba kijavítása érdekében szükséges időbefektetés, mely nem pénzben kifejezhető erőfeszítéseket takar. A szolgáltatások sokféleségének megfelelően ez nagyon sokféle típusú többlet-erőfeszítést jelenthet, néhány példával szeretnénk illusztrálni: ilyen eset, amikor a piszkos szobát ki kell takarítani, ezért a vevő azt nem tudja időben átvenni, és csak néhány óra múlva tud visszajönni, amikor a fodrász az elrontott frizurát újra elkészíti, ezzel időveszteséget okozva a vevőnek, amikor az internetszolgáltató ki kell, hogy menjen a vevőhöz, mert a helyszínen tudja csak kijavítani a hibát, ezért a vevőnek otthon kell maradnia; amikor az autó nincsen készen az ígért időpontra, ezért vissza kell menni; amikor a ruha foltos marad a tisztítás után, és csak másnapra lesz megfelelően kitisztítva.

Így aztán a szolgáltatóknak érdemes minden hibahelyzetet követően felmérni azt, hogy a vevőnek mekkora erőfeszítésébe, költségébe került az, hogy a vállalat tévedését korrigálják, mivel ez meghatározza az elvárt kártérítés mértékét. Ennek fényében pedig relevánsnak tartjuk a többlet-erőfeszítés hatásának vizsgálatát a túlkompenzációval kapcsolatos fogyasztói magatartás tükrében.

Szeretnénk hangsúlyozni, hogy az itt bemutatott többlet-erőfeszítés koncepciója nem azonos a panaszkezelés szakirodalmában elterjedt procedurális igazság dimenziójával. Ennek során általában a panaszkezelés során a kárpótláshoz való hozzájutás és magának a panaszkezelésnek a folyamatában jelentkező vevői igazságérzet jelenik meg, mint például a panasz felvételétől a kárpótlás megkapásáig eltelt idő, vagy a panasz megtételének folyamatában jelentkező problémák. Erre vonatkozóan Wirtz és Mattila (2004) kutatási eredménye alapján elmondhatjuk, hogy a jól menedzselt panaszkezelés megfelelő bocsánatkéréssel valóban csökkentheti a kárpótlás iránti igényt. A kutatásunkban feltárt többlet-erőfeszítés során azonban nem a panaszkezelés menetében van a hiba, hanem magának a szolgáltatás újrateljesítésének, vagy a kárpótlás igénybevételének a módja okoz a vevő részére plusz erőfeszítést, függetlenül a szolgáltató legtökéletesebb panaszkezelési folyamatától.

\section{Kutatási hipotézisek}

Hipotéziseinket a szakirodalmi kutatás és a mélyinterjúk eredményei alapján két nagy témakör köré csoportosítottuk, így egyrészt a panaszkezelés során a vevői erőfeszítések mértékére, másrészt a kompenzáció formájára vonatkozóan fogalmaztunk meg feltételezéseket.

Mielött rátérnénk kutatásunk központi tényezőjének vizsgálatára, fontosnak tartjuk azon kvalitatív kutatásból feltárt eredményünk tesztelését, amely szerint a vevők alapvetően nem pénzbeli kártérítést kívánnak, hanem egyszerüen szeretnék a szolgáltatás rendeltetésszerü megvaló- sulását. Roschk és Gelbrich (2014) kutatásában kimutatta, hogy a vevők a szolgáltatási hibának megfelelő kompenzációval lesznek a legelégedettebbek. Abban az esetben, ha a szolgáltatás újrateljesíthető, akkor elsősorban azt várják el, hogy a szolgáltató végezze el a szolgáltatást hibátlanul. Feltételezésünk szerint azonban ez csak abban az esetben igaz, ha nem kell valamilyen módon többlet-eröfeszítést tenniük a megvalósulásért. Ennek fényében első hipotézisünk:

H1: Abban az esetben, ha a fogyasztónak nincs különösebb többletmunkája a szolgáltatás újrateljesitését illetöen, nem vár el külön pénzügyi kompenzációt, hanem megelégszik a szolgáltatás megfelelö újrateljesitésével.

Feltáró kutatási eredményeink alapján arra a feltételezésre jutottunk, hogy a kompenzációval való elégedettséget nemcsak annak mértéke, hanem a hozzájutásához való erőfeszítés mértéke is meghatározza. Második hipotézisünk a mélyinterjúban bemutatott többlet-erőfeszítés panaszkezeléssel való elégedettségre gyakorolt hatásával kapcsolatos. Előzetes kutatásaink alapján azt feltételezzük, hogy a fogyasztók elégedettebbek lesznek a panaszkezeléssel akkor, ha nem kell különösebb erőfeszítést tenniük a hiba kijavítása érdekében. Gelbrich és társai (2016) úgy vélik, hogy az emberek többsége törekszik a panasztétel során olyan kompenzáció elnyerésére, mely az egyenlőség kialakulásához vezet. Ezt az állítást a többlet-eröfeszítés kontextusába illesztve elmondható, hogy amennyiben a fogyasztóknak jelentős többlet-erőfeszítést kell tenniük annak érdekében, hogy hozzájussanak a hibátlan szolgáltatáshoz, abban az esetben az egyenlő kompenzációt a vételáron felül nyújtott többletkárpótlás fogja jelenteni, mely plusz összeg hozzájárul az egyenlőség kialakulásához. Így pedig a fogyasztók egy jelentős többlet-erőfeszítést igénylő szituáció során a tranzakciót akkor fogják igazságosnak tartani, ha a szolgáltató vételáron felüli kártérítést is nyújt számukra. A hiba kijavításának eredményét két tényező mentén, az elégedettség és az igazságosság észlelésének tükrében vizsgáljuk. Mind az elégedettség, mind az igazságosság a panaszkezelés fontos és sokszor vizsgált eredménytényezője (Wirtz \& Mattila, 2004; Smith \& Bolton, 1998; Blodgett et al., 1997), ezért jelen kutatásban is e két függő változóra vonatkoztatjuk hipotéziseinket.

H2: Ha az ügyfélnek jelentős eröfeszitést kell tennie a szolgáltatási hiba kijavitása érdekében, (a) elégedetlenebb lesz a szolgáltató panaszkezelésével és (b) igazságtalanabbnak fogja azt tartani.

Első hipotézisünk arra vonatkozott, hogyha nincs szükség többlet-erőfeszítésre, a vevő nem vár el különösebb kompenzációt az újrateljesítésen felül. Második hipotézisünkben pedig arra utaltunk, hogy abban az esetben, ha a vevőnek többlet-erőfeszítést kell tennie a hiba kijavítása érdekében (függetlenül a kompenzáció mértékétől), kevésbé lesz elégedett a panaszkezeléssel és kevésbé fogja azt igazságosnak tartani. Ezt a két hipotézist tovább árnyalhatjuk az interakciós hatást figyelembe véve: abban az esetben, ha szükséges a többlet-erőfeszítés, az elégedettség növelhető a túlkompenzációval, míg ugyanez nem igaz az erőfeszítés hiányá- 
ra, hiszen ebben az esetben a túlkompenzációnak nem lesz elégedettségnövelő hatása. Feltételezésünk szerint tehát abban az esetben, ha a vevőnek jelentős többlet-erőfeszítést kell tennie, akkor jelentősen megnő mind az elégedettsége, mind pedig az igazságosságérzete a túlzott kompenzáció esetében.

H3: Ha az ügyfélnek jelentős erőfeszitést kell tennie a szolgáltatási hiba kijavitása érdekében, abban az esetben a többlet-erőfeszitést is megtéritő, azaz túlkompenzáló kártéritéssel lesz (a) elégedettebb és (b) fogja igazságosnak tartani, míg ha nem kell többlet-eröfeszitést tennie, nem lesz szignifikáns különbség a túlkompenzáció és a kompenzáció hiánya között.

A túlkompenzáció fogyasztói magatartásra gyakorolt hatása a kompenzációs típusnak is függvénye (Roschk \& Gelbrich, 2014; Noone \& Lee, 2012; Noone, 2011; Crisafulli \& Singh, 2016). Különbséget tehetünk készpénzalapú és kuponjellegű túlkompenzáció között, mely két típus időzítésben, bizonytalanságban és a flexibilitásban is eltér egymástól. E háromfajta különbség mind a készpénzalapú túlkompenzáció mellett szól: az időzítést tekintve a fogyasztók az azonnal megszerezhető kompenzációt preferálják, a bizonytalanságot tekintve a garantált jogorvoslatot, míg flexibilitást tekintve a nagyobb felhasználhatósági rugalmassággal rendelkező kompenzációt részesítik előnyben. Crisafulli és Singh (2016), illetve Roschk és Gelbrich (2014) is egyetértenek abban, hogy a készpénzalapú túlkompenzációt jobbnak értékelik a fogyasztók, mint a kuponjellegű túlkompenzációt.

H4: A fogyasztók a készpénzalapú túlkompenzációval (a) elégedettebbek lesznek, és (b) igazságosabbnak tartják, mint a kuponjellegü túlkompenzációt, függetlenül az eröfeszités mértékétöl.

\section{Kutatási módszer}

A kvantitatív kutatás célja, hogy megvizsgálja a túlkompenzáció és az ügyfelek részéről kifejtendő többleterőfeszítés hatását a fogyasztói magatartásra. A kutatás módszertanául a szcenárióalapú kísérleti módszertan szolgál, mely módszer előzetesen kialakított forgatókönyveken alapszik. A szcenárióalapú kutatási módszer alkalmazása mellett szóló érvünk, hogy a módszer előzetesen kialakított forgatókönyveken alapszik, amelyek segítik a válaszadót abban, hogy könnyebben azonosuljon az adott helyzettel, mely pontosabb fogyasztói reakciókat, válaszokat eredményezhet (Kenesei \& Kolos, 2008). Nem véletlen, hogy a kísérleti módszertan a legelterjedtebb a panaszkezelés kutatása során (lásd 1. táblázat).

A kísérletben két független változó hatását kívántuk vizsgálni. Első független változóként, a kompenzáció mértéke és típusa alapján három szintet határoztunk meg.

- Kompenzáció mértéke és típusa:

o szolgáltatás újrateljesítése egyéb kompenzáció nélkül,

o a szolgáltatás újrateljesítése és a teljes összeg visszafizetése készpénzben (100\%-os túlkompenzálás készpénzzel),

o a szolgáltatás újrateljesítése és a teljes összeg visszafizetése kuponnal (100\%-os túlkompenzálás kuponnal).
A három szint kialakításában fontos szempont volt, hogy összehasonlítsuk a kompenzáció hiányát (egyszerü újrateljesítés) a jelentős többletkompenzációval, illetve a kupon hatását a készpénzalapú kompenzációval. A teljes kompenzáció hatását ebben a kialakításban nem vizsgáltuk elsősorban azért, mert célunk a túlzott összegü kompenzáció hatásának a vizsgálata, olyan szolgáltatások esetében, ahol lehetséges az újrateljesítés. Látható, hogy a három szint két változó hatását ötvözi (kompenzáció mértéke és formája). Az ilyen típusú változókialakítás nem példa nélküli a szolgáltatáskutatásban, Sirianni és szerzőtársai (2013) hasonlóképpen vizsgálták a szolgáltatásmárkák autentikusságát.

Második független változónk, a feltáró kutatás alapján kirajzolódott többlet-erőfeszítésre vonatkozik, amelynek két szintjét határoztuk meg

- Erőfeszítés mértéke:

o jelentős többlet-erőfeszítés,

o jelentéktelen többlet-erőfeszítés.

A szcenáriókon alapuló kísérlet elvégzéséhez 2x3-as between-subject típusú faktoriális elrendezést alkalmaztunk, amelyhez 6 forgatókönyv kialakítására volt szükség. A független változók manipulálása segítségével kialakított forgatókönyvek véletlenszerüen kerültek kisorsolásra a válaszadók között, valamint minden szcenárióval közel azonos számú kitöltő találkozott.

A szcenáriók kialakítása során egy olyan kontextust kerestünk, amely elég hétköznapi és jól beilleszthető az egyes manipulációkba. A ruhatisztítás, mint szolgáltatás nyújtotta ezt a lehetőséget, és a szolgáltatási hiba a ruha gyürött volta. A szcenáriók kialakítása során törekedtünk arra, hogy mind a jelentéktelen mértékü többlet-erőfeszítés (azonnal újra kivasalják a ruhát), mind pedig a jelentős mértékü többlet-erőfeszítés (vissza kell jönni újra a vasalt ruháért) helyzetekben azonos típusú hibával találkozzanak a válaszadók. Ha a ruhatisztítóban azonnal pótolják a mulasztást, akkor a válaszadók jelentéktelen többlet-erőfeszítéssel találkoztak, míg az újbóli visszatérést igénylő helyzetek már jelentős többlet-erőfeszítést követeltek a szolgáltatást igénybe vevő alanytól. A kompenzáció három szintje pedig úgy módosult a három esetben, hogy a hibás teljesítést (gyűrött ruha) (1) újrateljesítik, (2) újrateljesítik és visszafizetik a szolgáltatás árát készpénzben, (3) újrateljesítik és visszafizetik a szolgáltatás árát egy legközelebb beváltható kupon formájában.

Ezen független változók eltérő szintjeinek és formájának függő változókra gyakorolt hatását kívánjuk megvizsgálni a primer kutatás során. Függő változóinkat szintén a szakirodalmi kutatás segítségével alakítottuk ki. Amint azt a szakirodalmi részben bemutattuk, számos kutatás vizsgálta a túlkompenzáció hatását e függő változókra, azonban jelentős eltérések figyelhetők meg az eredményekben. Épp ezért törekedtünk a korábbi kutatásokhoz hasonló függő változók meghatározására, mely segítségével tisztább képet kaphatunk arról, hogy mi az oka a korábbi kutatásokban megfigyelhető különbözőségeknek. Ez alapján pedig függő változóinkként egyrészt a kompenzá- 
ciós igazságosságot és a panaszkezelési elégedettséget határoztuk meg, amit egy-egy változóval mértünk (Gelbrich et al., 2016), illetve kiegészítettük azzal a kérdéssel, hogy vajon az adott helyzetben elvártak volna-e még addicionális kárpótlást (ezzel mintegy a kapott kárpótlás összegével való elégedettséget mértük).

A kutatásban a kísérleti módszertan elvárásai szerint törekedtünk arra, hogy minden cellába legalább 30, de 40-nél nem több kitöltő kerüljön, így összességében egy 223 fös (N) mintán teszteltük hipotéziseinket. A minta kényelmi minta volt, így a válaszok nem tekinthetők reprezentatívnak, azonban a kísérleti módszertan által vizsgált összefüggések feltárására alkalmas. A felméréshez a Qualtrics kérdőívszerkesztőt használtuk, amely biztosította a szcenáriók véletlenszerủ megkérdezetthez kerülését. A feldolgozás során az SPSS 23.00 statisztikai programcsomagot használtuk. tatott független változók eltérő szintjeit, így e szituációk alkalmasnak bizonyultak ok-okozati kapcsolatok vizsgálatára. A külső érvényesség vizsgálata során bebizonyosodott, hogy a válaszadók valóságosnak tarják a kísérlet során megismert szituációkat (a helyzetek valóságosságát a megkérdezettek 3,22 és 4,03 között értékelték 1-5-ig tartó skálán).

\section{Eredmények}

$\mathrm{Az}$ eredményeink bemutatását először a kárpótlás mértékére vonatkozó elégedettségre vonatkozóan tesszük meg, majd rátérünk a panaszkezeléssel való elégedettség és az igazságosság dimenziójára. Az 1. táblázatban közöljük a vizsgált változóink átlagértékeit a manipulált változóink függvényében. A továbbiakban ezen átlagértékek eltéréseit elemezzük.

1. táblázat Átlagértékek

(Likert-skála, 1-5-ig)

\begin{tabular}{|l|l|c|c|c|}
\hline \multirow{4}{*}{ Erőfeszítés } & Kompenzáció & $\begin{array}{c}\text { Magasabb kompenzációs elvárás } \\
\text { (fordított skála) }\end{array}$ & $\begin{array}{c}\text { Szolgáltatással való } \\
\text { elégedettség }\end{array}$ & Igazságosság \\
\hline \multirow{5}{*}{ Nincs erőfeszítés } & Nincs kompenzáció & 2,17 & 3,10 & 4,17 \\
\cline { 2 - 5 } & Kuponjellegú túlkompenzáció & 2,43 & 4,04 & 4,36 \\
\cline { 2 - 5 } & Készpénzalapú túlkompenzáció & 1,84 & 4,07 & 4,67 \\
\cline { 2 - 5 } & Nincs erőfeszítés átlaga & 2,11 & 3,70 & 4,41 \\
\hline \multirow{5}{*}{ Van erőfeszítés } & Nincs kompenzáció & 2,91 & 2,19 & 3,47 \\
\cline { 2 - 5 } & Kuponjellegú túlkompenzáció & 2,12 & 3,46 & 4,32 \\
\cline { 2 - 5 } & Készpénzalapú túlkompenzáció & 1,70 & 3,51 & 4,57 \\
\cline { 2 - 5 } & Van erőfeszítés átlaga & 2,21 & 3,11 & 4,15 \\
\hline \multirow{5}{*}{ Total } & Nincs kompenzáció & 2,49 & 2,70 & 3,86 \\
\cline { 2 - 5 } & Kuponjellegú túlkompenzáció & 2,25 & 3,70 & 4,33 \\
\cline { 2 - 5 } & Készpénzalapú túlkompenzáció & 1,78 & 3,81 & 4,63 \\
\cline { 2 - 5 } & Mintaátlag & 2,16 & 3,41 & 4,28 \\
\hline
\end{tabular}

Forrás: saját szerkesztés

A kérdőív kialakítása során gondoskodtunk a külső és a belső érvényesség vizsgálatának biztosításáról is, amelyet ANOVA módszerrel ellenőriztünk. A két típusú érvényesség különbözősége azok céljában mutatkozik meg. A belső érvényesség (manipulation check) elemzése választ ad arra, hogy vajon a függő változókban végbement változásokat a független változók szintjeinek manipulálása eredményezte-e. Ezzel szemben a külső érvényesség (reality check) célja annak meghatározása, hogy a kapott eredmények általánosíthatók-e (Malhotra, 2001). A belső érvényesség vizsgálata során megállapítottuk, hogy az erőfeszítés mértéke esetében szignifikáns eltérés van a két csoport átlaga között, tehát a manipuláció működik. A túlkompenzáció mértéke és típusa esetében szintén szignifikáns eltérés van a csoportok átlagai között, az átlagos értékek vizsgálata rámutatott, hogy a kompenzáció hiánya mutatja a legnagyobb eltérést a két másik túlkompenzációs összeghez képest, míg a készpénzalapú és a kuponjellegű túlkompenzáció esetében csak a kártérítés formájában mutatkozik lényeges különbség. Összességében a belső érvényesség megléte arra enged következtetni, hogy a kitöltők megfelelően észlelték az egyes szituációkban bemu-
A következő részben hipotéziseink mentén megvizsgáljuk, hogy ezen átlagok szignifikánsan eltérnek-e egymástól.

A fogyasztói többlet-erőfeszités és a kompenzáció mértékének a hatása az elözetesen elvárt kompenzáció mértékére

Első hipotézisünk arra vonatkozott, hogy a vevők számára egy újrateljesíthető szolgáltatás esetén a panasz megfelelö kezelése azt jelenti, hogy a szolgáltatást újra elvégzik hiba nélkül. Feltételezésünk szerint nem várnak el plusz pénzügyi kompenzációt a hiba kijavításán túl abban az esetben, ha a hiba kijavítása nem jelent számukra semmilyen jelentősebb extra erőfeszítést. Ennek a hipotézisnek a tesztelésére a fogyasztók kárpótlásra vonatkozó elvárásait vizsgáltuk a különböző szcenáriók esetében. Többszempontos varianciaelemzéssel (ANOVA) megvizsgáltuk a kártérítés mértékének hatását (független változó) a kárpótlás összegére vonatkozó elvárásokra (függő változó), amelyet azzal a kérdéssel mértünk, hogy vajon elvártak volna-e magasabb összegü kárpótlást az adott esetben (a skála tehát itt fordított, hiszen az egyetértés azt jelezte, hogy magasabb kompenzációs igényük volt). 
2. táblázat Fő és interakciós hatások a kompenzációs elvárásokra

Függő változó: Ebben a helyzetben ennél magasabb összegü kárpótlásra számítanék.

\begin{tabular}{|l|c|c|c|c|c|c|}
\hline Független változó & Type III Sum of Squares & df & Mean Square & F & Sig. & Partial Eta Squared \\
\hline Eröfeszítés mértéke & 0,538 & 1 & 0,538 & 0,398 & 0,529 & 0,002 \\
\hline Kompenzáció & 23,209 & 2 & 11,605 & 8,583 & 0,000 & 0,073 \\
\hline Eröfeszítés*Komp & 11,273 & 2 & 5,637 & 4,169 & 0,017 & 0,037 \\
\hline R Squared =,099 (Adjusted R Squared =,078)
\end{tabular}

Forrás: saját szerkesztés

A 2. táblázatban bemutatott eredmények arra utalnak, hogy míg az erőfeszítésnek nincs szignifikáns föhatása $(\mathrm{p}=0,53)$, addig az interakciós hatás már jelentős $(\mathrm{p}<0,001)$. Érdemes tehát megvizsgálni a kétféle erőfeszítés-típusra vonatkozóan az eredményeket. Az 1. ábrán megfigyelhető átlagértékek összehasonlítása azt mutatja, hogy abban az esetben, ha a fogyasztónak nem kell jelentős erőfeszítést tennie a hiba kijavítása érdekében, az átlagértékek az egyes kompenzációs szintek között nem különböznek egymástól jelentősen. A 3. táblázat alapján a Tukey-féle post hoc teszttel az egyes szintek egymáshoz viszonyított eltérésének szignifikanciaszintjét tudjuk tesztelni. Hipotézistesztelésünk szempontjából a „nincs erőfeszítés" értékei a fontosak, amelyek a teszt eredménye alapján egyik esetben sem térnek el egymástól szignifikánsan, azaz a válaszadók nem vártak volna el magasabb kompenzációt abban az esetben sem, amikor semmilyen plusz pénzügyi elönyhöz nem jutottak a panaszkezelés kapcsán. Ezzel első hipotézisünk igazolást nyert.

Ezzel ellentétben abban az esetben, ha a fogyasztónak erőfeszítést kell tennie, jelentős eltérés van az elvárásait tekintve, hiszen a szimpla újrateljesítéskor szignifikánsan magasabb összegü kártérítésre vártak volna a válaszadók (Mnincs komp, van erőfeszítés = 2,9), mint akár a kupon, akár a készpénzes túlkompenzáció esetében (Mkupon, van erőfeszítés $=2,1 ; \mathrm{p}<0,05 ;$ Mkészpénz, van erőfeszítés $=1,7$; $\mathrm{p}<0,001)$.

$\mathrm{Az}$ 1. ábra az átlagértékeket a függő változók eltérő szintjei mellett mutatja be, amely így jól láthatóvá teszi az erőfeszítés mértékének eltérő hatását a kompenzációs elvárásokra. Az ábra szemlélteti azt, hogy az erőfeszítés mértéke abban az esetben válik fontossá, amikor a vevők nem kapnak semmiféle kompenzációt. Abban az esetben, ha kapnak, az erőfeszítésnek nincs jelentősége az elvárások alakulásában.
1. ábra Az erőfeszítés és a kompenzáció hatása az elvárt kompenzációra

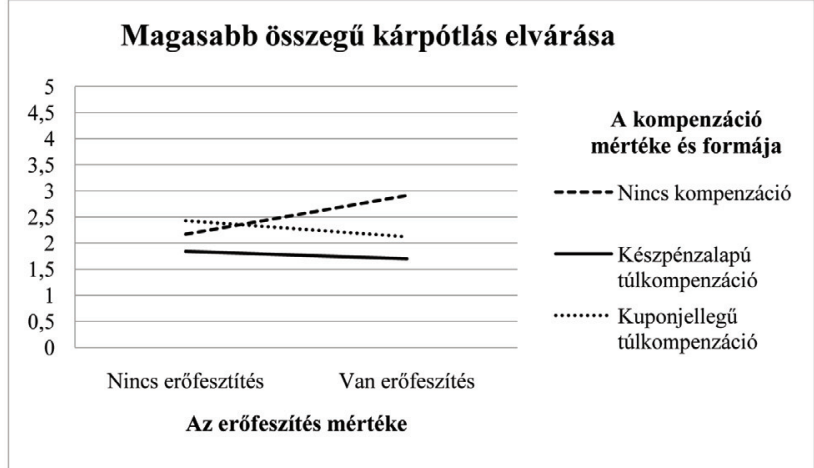

1: egyáltalán nem értek egyet vele,

5: teljes mértékben egyetértek vele

Forrás: saját szerkesztés

Eredményeink ismeretében első hipotézisünket elfogadjuk, így kijelenthetjük, hogy abban az esetben, ha a vevőnek nem kell különösebb erőfeszítést tennie azért, hogy a szolgáltatást kijavítsák, az újrateljesítésen felül nem igényel többlet kompenzációt.

A következőkben azt kívánjuk megvizsgálni, hogyha a fogyasztó elözetes elvárásai nem is vonatkoznak magasabb összegü kompenzációra az erőfeszítés hiányában, vajon elégedettebbé teszi-e őket a túlkompenzáció.

A fogyasztói többlet-erőfeszités és a kompenzáció mértékének hatása a szolgáltatással való elégedettségre

A második és negyedik hipotézis (a) részének tesztelését a független változók szolgáltatással való elégedettségre gyakorolt föhatásának vizsgálata jelenti. Mivel ebben az esetben szeretnénk megismerni a fogyasztók részéről felmerült többlet-erőfeszítésnek és a

3. táblázat A kompenzációs formák és összegek szintjeinek hatásbeli különbözősége a kompenzációs elvárásokban (Tukey-teszt)

\begin{tabular}{|c|c|c|c|c|c|c|c|}
\hline \multicolumn{2}{|c|}{ Erőfeszítés mértéke } & \multicolumn{3}{|c|}{ Nincs erőfeszítés } & \multicolumn{3}{|c|}{ Van erőfeszítés } \\
\hline \multicolumn{2}{|c|}{ Kompenzáció szintjei } & Átlag-eltérés & Std.hiba. & Szign & Átlag-eltérés & Std. hiba & Szign \\
\hline \multirow{2}{*}{$\begin{array}{l}\text { Nincs } \\
\text { kompenzáció }\end{array}$} & Készpénzalapú túlkompenzáció & 0,33 & 0,25 & 0,385 & $1,20 * *$ & 0,28 & 0,000 \\
\hline & Kuponjellegű túlkompenzáció & $-0,26$ & 0,28 & 0,618 & $0,78^{*}$ & 0,28 & 0,016 \\
\hline \multirow{2}{*}{$\begin{array}{l}\text { Készpénzalapú } \\
\text { túlkompenzáció }\end{array}$} & Nincs kompenzáció & $-0,33$ & 0,25 & 0,385 & $-1,20^{* *}$ & 0,28 & 0,000 \\
\hline & Kuponjellegű túlkompenzáció & $-0,59$ & 0,28 & 0,090 & $-0,42$ & 0,27 & 0,264 \\
\hline \multirow{2}{*}{$\begin{array}{l}\text { Kuponjellegü } \\
\text { túlkompenzáció }\end{array}$} & Nincs kompenzáció & 0,26 & 0,28 & 0,618 & $-0,78^{*}$ & 0,28 & 0,016 \\
\hline & Készpénzalapú túlkompenzáció & 0,59 & 0,28 & 0,090 & 0,42 & 0,27 & 0,264 \\
\hline
\end{tabular}

Forrás: saját szerkesztés 
kompenzáció eltérő szintjeinek és formáinak együttes hatását, így ismét egy többszempontos varianciaelemzést (ANOVA) hajtottunk végre. Az F-próbához tartozó szignifikanciaszint alapján megállapítható, hogy az erőfeszítés és a túlkompenzáció ebben az esetben hatással van az elégedettségre, míg a két független változó interakciója nem befolyásolja az elégedettség e típusának szintjét. A parciális Eta2 mutató alapján az erőfeszítés mértéke 9,8\%-ban, a kompenzáció típusa és mértéke pedig 21,1\%-ban magyarázza a panaszkezeléssel való elégedettség szórását. Az R2 mutató szerint a többleterőfeszítés és a kártérítés a kompenzációval kapcsolatos elégedettség 24,5\% -át magyarázzák (4. táblázat). Az eredmények alapján fontos kiemelni, hogy a kártérítés összege és formája sokkal nagyobb hatással van a panaszkezeléssel való elégedettségre, mint a többlet-erőfeszítés mértéke. $(\mathrm{p}<0,05)$, míg kártérítés formája tekintetében nincs meghatározó eltérés e függő változó szintjeit tekintve ( $p>0,05)$ egyik erőfeszítés-helyzet esetében sem, így érdemes megvizsgálni a 2. ábrát. A 2. ábra vízszintes tengelye a fogyasztói többlet-erőfeszítés egyes szintjeit, míg az ábrán található vonalak a kompenzáció mértékét és típusát reprezentálják. Az ábrán látható egyenesek párhuzamossága egyértelműen jelzi, hogy a készpénz és a kuponjellegű túlkompenzáció mindkét erőfeszítés-típus esetében szignifikánsan magasabb elégedettséghez vezet. Ennek tükrében a harmadik hipotézisünk (a) részét el kell utasítanunk.

4. táblázat Fő és interakciós hatások a szolgáltatással való elégedettségre

Függö változó: Ebben az esetben mennyire elégedetten távozott volna a ruhatisztítóból?

\begin{tabular}{|l|c|c|c|c|c|c|}
\hline \multicolumn{1}{|c|}{ Független változó } & $\begin{array}{c}\text { Type III Sum of } \\
\text { Squares }\end{array}$ & df & Mean Square & F & Sig. & $\begin{array}{c}\text { Partial Eta } \\
\text { Squared }\end{array}$ \\
\hline Eröfeszítés mértéke & 25,062 & 1 & 25,062 & 23,474 & 0,000 & 0,098 \\
\hline Kompenzáció & 62,142 & 2 & 31,071 & 29,101 & 0,000 & 0,211 \\
\hline Erőfeszítés*Komp & 1,439 & 2 & 0,720 & 0,674 & 0,511 & 0,006 \\
\hline R Squared =,262 (Adjusted R Squared =,245)
\end{tabular}

Forrás: saját szerkesztés

A főhatások vizsgálata során arra jutottunk, hogy az erőfeszítés hiánya esetén magasabb a kompenzációval kapcsolatos elégedettség átlagos szintje, mint a jelentős többlet-erőfeszítést igénylő helyzetekben (Mnincs erőfeszítés = 3,7; Mvan erőfeszítés = 3,11; p<0,000). Ezen eredmény alapján a második hipotézis (a) részét elfogadjuk.

A kompenzáció különböző szintjeit tekintve - nem meglepő módon - a kártérítés hiánya kapcsán figyelhetjük meg a függő változó legalacsonyabb szintjét (Mnincs komp $=2,70)$, míg a készpénz és kuponjellegü túlkompenzációt biztosító változók átlagai között nincs jelentős különbség a panaszkezeléssel való elégedettség átlagaiban (Mkupon= 3,70; Mkészpénz = 3,81; nem szign.). A Tukey-teszt alapján (1. melléklet) a negyedik hipotézisünk (a) részét el kell utasítanunk, azaz a kompenzáció formája nem befolyásolja a szolgáltatással való elégedettséget.

Mindannak ellenére, hogy a független változók interakciós hatásának elemzése során elsőként arra jutottunk, hogy a független változók interakciós hatása nem befolyásolja szignifikánsan a függő változó szintjeit, azonban a Tukey-elemzés segítségével finomítható az összefüggés-vizsgálat. Negyedik hipotézisünk szerint abban az esetben, ha a vevő részéről szükséges a többleteröfeszítés, a túlkompenzációval lesz elégedettebb, míg ha nem kell erőfeszítést tennie, nem lesz ilyen eltérés. A Tukey-teszt eredménye (1. melléklet) arra utal, hogy a panaszkezeléssel való elégedettség szintjei közötti különbség a kompenzációs összeg szerint szignifikáns
2. ábra Az erőfeszítés és a kompenzáció hatása a szolgáltatással való elégedettségre

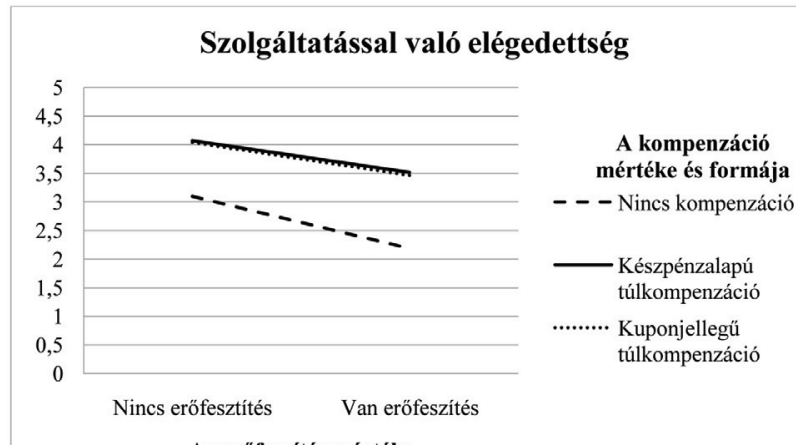

Az erőfeszítés mértéke

1: egyáltalán nem lettem volna elégedett,

5: teljes mértékben elégedett lettem volna Forrás: saját szerkesztés

A fogyasztói többlet-erőfeszités és a kártalanitás szintjének és formájának a panaszkezelés észlelt igazságosságára gyakorolt hatása

A második és negyedik hipotézisünk (b) részének tesztelése érdekében megvizsgáltuk a fogyasztók részéről kifejtendő többlet-erőfeszítés és a kártalanítás eltérő szintjeinek és formájának a függő változóra - panaszkezelés észlelt igazságossága - gyakorolt főhatását, melynek megismerése érdekében ismét többszempontos varianciaelemzést (ANOVA) hajtottunk végre. Az F-próbához tartozó szignifikanciaszint alapján elmondható, hogy míg az erőfeszítés és a kompenzáció eltérő szintjei külön-külön szignifikánsan hatnak a 
panaszkezelés észlelt igazságosságára $(\mathrm{p}<0,05)$, addig e két tényező interakciója nincs szignifikáns hatással a függő változónk eltérő szintjeire, - mivel a szignifikanciaszint némileg meghaladja az 5\%-os hibahatárt. A parciális Eta2 azt mutatja, hogy az erőfeszítés az igazságosság szórásának 2,2\%-át magyarázza, míg a kompenzáció az igazságosság szórásának 11,5 százalékáért felel. Ezek alapján elmondható, hogy a fogyasztók részéröl kifejtendő többlet-erőfeszítéshez képest a kompenzáció az igazságosság szórásának több mint ötszörösét indokolja. Az R2 mutató szerint e modell az igazságosság eltérő szintjeinek 14,1\%-át magyarázza (5. táblázat).
Noha az interakciós hatás az 5. táblázat alapján nem szignifikáns $(p=0,071)$, mégis a 3 . ábra alapján érdemesnek tartjuk ellenőrizni Tukey-teszttel, hogy a kompenzáció megléte (akár kuponnal, akár készpénzzel) és hiánya között van-e különbség az erőfeszítés különböző szintjei mellett. Az ábrán jól látható, hogy az erőfeszítés mértéke egyedül a kompenzáció hiánya esetén tünik befolyásoló erejünek (azaz az ezt jelölő vonal nem vízszintes).

A Tukey-próba eredménye (2. melléklet) arra enged következtetni, hogy a többlet-erőfeszítés megléte esetén szignifikánsan magasabb észlelt panaszkezelési igazsá-

5. táblázat Fő és interakciós hatások az igazságosságra

Függő változó: Mennyire érzi igazságosnak azt, ahogyan a panaszát kezelték?

\begin{tabular}{|l|c|c|c|c|c|c|}
\hline Független változó & Type III Sum of Squares & df & Mean Square & F & Sig. & Partial Eta Squared \\
\hline Eröfeszítés mértéke & 4,314 & 1 & 4,314 & 4,885 &, 028 &, 022 \\
\hline Kompenzáció & 24,961 & 2 & 12,480 & 14,132 &, 000 &, 115 \\
\hline Eröfeszítés*Komp & 4,726 & 2 & 2,363 & 2,676 &, 071 &, 024 \\
\hline
\end{tabular}

Forrás: saját szerkesztés

A főhatásokat vizsgálva megállapítottuk, hogy az erőfeszítés hiánya esetén a kitöltők a panaszkezelés igazságosságának magasabb szintjeit észlelték, szemben a fogyasztói többlet-erőfeszítést igénylö szituációkkal $\left(\mathrm{M}_{\text {nincs }}\right.$ eröfeszítés $\left.=4,41 ; \mathrm{M}_{\text {van erőfeszités }}==4,15 ; \mathrm{p}<0,05\right)$. Ezen eredmény alapján második hipotézisünk (b) részét elfogadjuk.

A kompenzáció eltérő szintjeit és formáit tekintve világossá vált, hogy amennyiben a károsult fél nem kapott kompenzációt, abban az esetben volt a legalacsonyabb a függő változó szintje $\left(\mathrm{M}_{\text {nincs komp }}=3,86\right)$, míg a készpénzalapú túlkompenzáció eredményezte a legmagasabb észlelt igazságossági szintet, bár szignifikánsan nem magasabbat, mint a kuponos forma esetén $\left(\mathrm{M}_{\text {kupon }}=4,33\right.$; $\mathrm{M}_{\text {készpénz }}=4,63$; nem szign.). A két túlkompenzációs forma által kiváltott észlelt panaszkezelési igazságosság között tehát elenyésző a különbség, így negyedik hipotézisünk (b) részét elutasítjuk. Ezek alapján elmondható, hogy a fogyasztók igazságosságérzete szempontjából mindegy, hogy a vállalat kupon vagy készpénz formájában biztosítja számára a veszteségek megtérítését szolgáló kártérítést.

\section{3. ábra A panaszkezelés észlelt igazságossága} a fogyasztói erőfeszítés mértéke és a kompenzáció interakciós hatásának függvényében

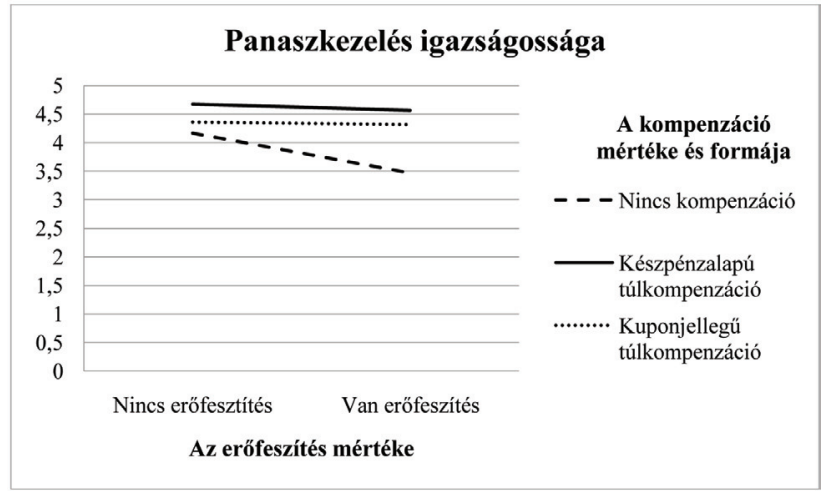

1: egyáltalán nem érzem igazságosnak,

5: teljes mértékben igazságosnak érzem Forrás: saját szerkesztés gosságról számoltak be a túlkompenzált válaszadóink, összehasonlítva azon kitöltőkkel, akik a szolgáltatás újrateljesítésén felül semmilyen kártérítésben nem részesültek $\left(\mathrm{M}_{\text {nincs komp, van eröfeszités }}=3,47 ; \mathrm{M}_{\text {kupon, van eröfeszités }}=4,32\right.$; $\mathrm{p}<0,01),\left(\mathrm{M}_{\text {nincs komp, van eröfeszités }}=3,47 ; \mathrm{M}_{\text {készpénz, van eröfeszités }}=\right.$ $4,57 ; \mathrm{p}<0,001)$. Tehát többlet-erőfeszítés esetében valóban van hatása a túlkompenzációnak.

Mindemellett a többlet-erőfeszítés hiánya esetén - a kuponjellegü túlkompenzációval szemben - a készpénzalapú túlkompenzáció szintén szignifikánsan magasabb észlelt igazságosságot eredményezett, összehasonlítva a kompenzáció hiányát megtestesítő helyzetekkel, bár kisebb mértékben, mint az erőfeszítés jelenléte esetén. Ezen eredmények alapján harmadik hipotézisünk (b) részét elfogadjuk.

\section{Következtetések és javaslatok Az eredmények összefoglalása}

Kutatási hipotéziseink tesztelésének eredményeit öszszefoglalva elmondhatjuk, hogy a kvalitatív interjúk alapján feltárt tényezőnek, a többlet-erőfeszítésnek valóban van hatása arra, hogy vajon a hiba kijavítása során milyen kompenzációt vár el a fogyasztó, mennyire lesz elégedett a szolgáltatással és menyire fogja azt igazságosnak érezni (H1, H2a, H2b). Ezen eredmény fényében elmondhatjuk, hogy abban az esetben, ha a szolgáltató a szolgáltatás során bekövetkezett hiba kijavítását csak úgy tudja megoldani, hogy az extra költséget jelent a vevőnek, legyen ez akár fizikai, akár időbeli, akár pénzbeli, számítania kell arra, hogy a vevő igényelni fogja az újrateljesítésen felül valamilyen plusz kompenzáció felajánlását. Amennyiben a méltányosság felől vizsgáljuk meg ezt az eredményt, feltételezhetjük, hogy a vevő számára akkor válik igazságossá a panaszkezelés, ha a vállalat figyelembe veszi az összes költséget, amely felmerül a hibás teljesítés, és annak korrigálása következtében. Fontos eredmény ennek fényében az is, hogy abban az esetben, ha nem igényel különösebb többlet-erőfeszítést a hiba kijavítása, a vevők nem számítanak többlet-pénzviszszafizetésre, azaz túlkompenzációra (H1). Mindazonáltal, 
ha kapnak, azzal elégedettebb lesznek, bár nem feltétlenül tartják igazságosabbnak (H3a, H3b) (6. táblázat). a fogyasztók a sérült kapcsolat során felmerült pszichológiai kárukat is igyekeznek megtéríttetni, melyre a túl-

6. táblázat Hipotézistesztelés eredménye

\begin{tabular}{|l|l|c|}
\hline \multicolumn{1}{|c|}{ Hipotézis } & Eredmény \\
\hline H1 & $\begin{array}{l}\text { Ha a vevőnek nem kell többlet-erőfeszítést tenni, akkor az újrateljesítésen felül nem igényel } \\
\text { plusz kompenzációt. }\end{array}$ & Elfogadva \\
\hline H2a & $\begin{array}{l}\text { Ha a vevőnek többlet-eröfeszítést kell tenni, a hiba kijavítása érdekében, elégedetlenebb lesz a } \\
\text { szolgáltatással. }\end{array}$ & Elfogadva \\
& $\begin{array}{l}\text { Ha a vevőnek többlet-erőfeszítést tenni kell a hiba kijavítása érdekében, igazságtalanabbnak } \\
\text { fogja érezni a panaszkezelést. }\end{array}$ & Elfogadva \\
\hline H2b & $\begin{array}{l}\text { Ha a vevőnek többlet-erőfeszítést kell tennie az újrateljesítés érdekében, a túlkompenzációval } \\
\text { nem lesz az elégedettségben különbség. }\end{array}$ & Elutasítva \\
\hline H3a & $\begin{array}{l}\text { Ha a vevőnek többlet-erőfeszítést kell tennie az újrateljesítés érdekében, a túlkompenzációt } \\
\text { igazságosabbnak fogja észlelni, míg ha nincs szükség többlet-erőfeszítésre, nem lesz az iga- } \\
\text { zságosság észlelésében különbség. }\end{array}$ & Elfogadva \\
\hline H3b & A vevők a készpénzalapú túlkompenzációval elégedettebbek lesznek. & Elutasítva \\
\hline H4a & A vevők a készpénzalapú túlkompenzációt igazságosabbnak tartják. & Elutasítva \\
\hline H4b &
\end{tabular}

Forrás: saját szerkesztés

A többlet-erőfeszítés mellett megvizsgáltuk a kompenzáció formájának hatását is, és arra a következtetésre jutottunk, hogy annak nincs különösebb szerepe sem az elégedettség, sem az igazságosság érzetének szempontjából (H3a, H3b). Az, hogy a szolgáltatóvállalat kupon vagy készpénz formájában nyújtja a túlkompenzációt nem befolyásolja a végeredményt.

\section{Elméleti és gyakorlati következtetések}

Eredményeink értelmezésekor érdemesnek látjuk a szakirodalmi részben bemutatott kutatásokat összevetni saját kutatásunkkal. Egyrészről megerősítettük azt a szakirodalomban elfogadott nézetet, amely szerint a vevők a panaszkezelés során egyeztetik elvárásaikat a hiba jellegével. Ennek megfelelően abban az esetben, ha a szolgáltatás újrateljesíthető, nem kompenzációt várnak el, hanem a szolgáltatás hibátlan teljesítését (Roschk \& Gelbrich, 2014). Saját kutatásunk ezt alátámasztotta, hiszen abban az esetben, ha a vevőnek nem kell többlet-erőfeszítést tennie az újrateljesítés érdekében, valóban nem vár el magasabb kompenzációt a hiba kijavításán túl.

A túlkompenzáció elégedettségre gyakorolt hatását tekintve már jelentős eltérések tapasztalhatóak a különböző kutatási eredmények között. Haesevoets és társai (2014) arra a következtetésre jutottak, hogy a túlkompenzáció esetén alacsonyabb elégedettségi szint figyelhetö meg, mint egyszerü kompenzáció esetén, ami az alacsonyabb észlelt méltányosság következménye. Az észlelt méltányosság alacsony szintje alacsony erkölcsösségre utal, mely a fogyasztói bizalmat is negatívan befolyásolja. Ezzel szemben Gelbrich és Roschk (2011) árnyalja a képet és egy meta-analízis segítségével megkülönbözteti a tranzakciós és össz-elégedettséget, kijelentve, hogy az egyszerü kompenzáció nagyobb mértékben növeli a tranzakcióspecifikus elégedettséget, mint a túlkompenzáció. Másrészt viszont az össz-elégedettség kialakítása során kompenzáció nyújt megoldást. Noone és Lee (2011) pedig egyenesen azt állapította meg, hogy a készpénzalapú túlkompenzáció magasabb elégedettséghez vezet, mint a teljes kompenzáció.

Kutatásunkban egyrészt megerősítettük ez utóbbi kutatók álláspontját, hiszen egyértelmüen magasabb elégedettséghez vezetett a túlkompenzáció, bármilyen formában nyújtsa is azt a vállalat. Elmondható tehát, hogy noha a vevők előzetesen nem várnak el jelentősebb kompenzációt, ettől függetlenül lehetséges, hogy mégis elégedettebbek lesznek, ha magasabb mértékü kompenzációban részesülnek az újrateljesítésen felül.

Az igazságosság tekintetében azonban már árnyalhatjuk a képet a kutatásban bevezetett új tényezö, a többleterőfeszítés vizsgálatával. Ez alapján akkor tekinti igazságosnak a vevő a túlkompenzációt, ha extra erőfeszítést kellett tennie a szolgáltatás újrateljesítése érdekében. Ha erre nem volt szükség, akkor igazságosságérzete nem növekedett a túlkompenzáció által.

Kutatásunk során nemcsak az erőfeszítés mértékét vizsgáltuk, hanem a kompenzáció formájának hatását is. Noone és Lee (2011) szerint a készpénzalapú túlkompenzáció magasabb elégedettséghez vezet, mint a teljes kompenzáció vagy a kuponjellegü túlkompenzáció. Noone szerint (2012) az észlelt kompenzációs igazságosság szintje nem emelkedik a készpénzalapú túlkompenzáció mértékének növelésével megegyező mértékben.

Érdekes módon saját kutatási eredményeink nem támasztották alá sem az elégedettségre, sem az észlelt igazságosságra vonatkozóan az előzetes feltételezéseinket. Ennek többféle oka lehet. Elsőként a szcenárióban kiválasztott szolgáltatás típusa lehet az egyik ok. Mivel a mosodai szolgáltatás egy kis értékü szolgáltatás, amelyet akár gyakrabban is igénybe vehetünk, nem jelentkezik a kétféle kompenzációs forma között az az intertemporális különbség, amelyet a kutatók elöre jelzenek (Zauberman, 2003), ezért a vevők nem értékelik 
többre a jelenben kapott előnyt a jövőben kapottal szemben. Az eredmény másik oka lehet, hogy a 200\%-os túlkompenzáció (újrateljesítés plusz a vételár visszatérítése) olyan jelentős, hogy ennek fényében eltörpül az, hogy a kompenzációt készpénz vagy kupon formájában kapja a vevő.

A kutatás menedzseri következtetései tekintetében eredményeink alapján elmondható, hogy a fogyasztók által észlelt panaszkezelési igazságosság elérése érdekében - jelentős többlet-erőfeszítés mellett - érdemes a szolgáltatóvállalatnak a hiba kijavításán, vagyis a szolgáltatás újrateljesítésén felül további kompenzációt nyújtania. A túlkompenzáció formáját illetően azonban nincs eltérés a panaszkezelés észlelt igazságosságára való tekintettel, illetve a szolgáltatással való elégedettségre, így a kártérítés formájával kapcsolatos döntéshez a vállalatnak más - például költséghatékonysági - szempontokra kell hagyatkoznia.

Fontosnak tartjuk azt is megjegyezni, hogy a szolgáltatónak tisztában kell lennie azzal, hogy a panaszhelyzetek kialakulása, és azok megoldása során a vevőnek milyen erőfeszítéseket kell tenni, hogy a szolgáltatást hibátlanul megkapja. Alapvető esetben természetesen arra kell törekednie, hogy minél kisebb mértékü legyen ez az erőfeszítés, hiszen eredményeink alapján ennek fontos hatása van mind az elégedettségre, mind az igazságosság észlelésére. Abban az esetben azonban, ha ez nem lehetséges, meg kell fontolni, hogy melyek ezek a fogyasztói erőfeszítések, és hogy milyen mértékủ túlkompenzáció teheti a panaszkezelés észlelését igazságossá. Ez egyrészt fontos a panaszkezelési stratégia és konkrét eszközök meghatározásakor, másrészt pedig a panaszkezelést teljesítő alkalmazottak képzése során. Mivel a panaszhelyzetek egy-egy vállalatnál változatosak tudnak lenni, lényeges, hogy az alkalmazottak megfelelö felhatalmazással rendelkezzenek annak érdekében, hogy kellő mértékben alkalmazkodni tudjanak a helyzethez és ennek megfelelő kompenzációt kínáljanak fel a károsult vevőnek.

\section{Kutatási korlátok és további kutatási lehetőségek}

Kvantitatív kutatásunk rendelkezik néhány korláttal, mely korlátokat szükséges figyelembe venni az eredmények értelmezése során. Első korlátként az önkényes mintavétel során elért kitöltők demográfiai jellemzőit említenénk meg. Ezen okból kifolyólag azonban jelen kutatás leíró jellegü következtetések levonására nem alkalmas (pl. elégedettségi szint mértéke). Kvantitatív kutatásunk második korlátját a szcenárióalapú kísérleti módszer jelentette. Úgy gondoljuk, hogy - bár a módszer a maga keretei között fontos eredményeket adott - ki lehetne egészíteni más típusú módszerekkel, mint például a kritikus esetek módszere. A szcenárióalapú kísérleti módszertan segítségével jelen kutatásban csupán a kártérítés két szintjét elemeztük - nincs kompenzáció, 100\%-os túlkompenzáció -, azonban érdemes lenne megvizsgálni további, a vételárat meghaladó kártérítési összegek fogyasztói magatartásra gyakorolt hatását is. Ennek révén lehetőség nyílna annak megismerésére, hogy melyik az a túlkompenzációs szint, amely mellett - a többlet-eröfeszítés egyes szintjei esetén - maximalizálódik a kártérítésből származó vállalati haszon. Emellett jelen kutatás a hiba korrigálása során fel- merült fogyasztói többlet-költségek több típusának - idő és pénzügyi költségek - variációját elemezte, azonban érdemes lenne megvizsgálni azt is, hogy a többlet-erőfeszítés egyes típusai szerint miként tér el a fogyasztók kompenzációra vonatkozó elvárása, valamint az egyes esetekben miként hat a túlkompenzáció a fogyasztói magatartásra. Vajon abban az esetben, amikor az ügyfélnek csupán jelentős időbeli költségei merülnek fel, abban az esetben is elvár valamiféle pénzügyi kártérítést, vagy megelégszik a hiba korrigálásával és a bocsánatkéréssel? Vagy, amennyiben pénzügyi többlet-erőfeszítés esetén várnak el a károsult vevők magasabb kártérítést, abban az esetben milyen mértékben haladja meg ezen elvárás az érzelmi költségek által kiváltott kompenzációs követelések szintjét? E kérdések vizsgálatával további segítséget nyújthatunk a szolgáltató vállalatok számára a legmegfelelőbb kompenzációs szint kiválasztására. Kvantitatív kutatásunk korlátai között szintén meg kell említenünk a szolgáltatási kontextust. Mivel kutatásunk csupán a ruhatisztítóban felmerült hibára és korrigálására korlátozódott, ezért érdemesnek tartjuk megvizsgálni a fogyasztói többlet-erőfeszítés és a kártérítés egyes szintjeinek és formáinak a fogyasztói magatartásra gyakorolt hatását más szolgáltatási környezetben is. A kialakított forgatókönyvek esetén olyan panaszhelyzeteket hoztunk létre, amelyek szerint a fogyasztónak nincs korábbi vásárlási tapasztalata az adott szolgáltatónál. A korábbi vásárlási tapasztalat meglétének és hiányának a kompenzációs elvárásokra gyakorolt hatásának fontosságát azonban Estelami és Maeyer (2002) is kiemelni. Eszerint pedig a jövőbeli kutatásoknak érdemes lenne megvizsgálniuk azt is, hogy miként hat a fogyasztói többlet-erőfeszítés mértéke a kompenzációs elvárásokra akkor, amikor a károsult ügyfél visszatérő vagy új vásárlója az adott szolgáltatónak, valamint e kártérítési összeg miként befolyásolja a fogyasztó panaszkezelés utáni magatartását. E szempont részletes elemzése pedig további segítséget ad a vállalatoknak az optimális kártérítési összeg kialakítására.

\section{Felhasznált irodalom}

Blodgett, J. G., Hill, D. J., \& Tax, S. S. (1997). The effects of distributive, procedural, and interactional justice on postcomplaint behavior. Journal of Retailing, 73(2), 185-210.

Charmaz, K. (2000): Grounded theory. Objectivist and constructivist method. in N. Denzin \& Y. Lincoln (Eds.), Handbook of Qualitative Research (pp. 509536). Thousand Oaks, CA: Sage.

Crisafulli, B., \& Singh, J. (2016). Service guarantee as a recovery strategy: The impact of guarantee terms on perceived justice and firm motives. Journal of Service Management, 27(2), 117-143.

Davidow, M. (2003). Organizational responses to customer complaints: What works and what doesn't. Journal of Service Research, 5(3), 225-250.

Estelami, H., \& Maeyer, P.D. (2002). Customer reactions to service provider overgenerosity. Journal of Service Research, 4(3), 205-216.

Garrett, D.E. (1999). The effectiveness of compensation given to complaining consumers: is more better? 
Journal of Consumer Satisfaction, Dissatisfaction and Complaining Behavior, 12, 26-34.

Gelbrich, K., \& Roschk, H. (2011). Do complainants appreciate overcompensation? A meta-analysis on the effect of simple compensation vs. overcompensation on post-complaint satisfaction. Marketing Letters, 22(1), 31-47.

Gelbrich, K., Gäthke, J., \& Grégoire, Y. (2015). How much compensation should a firm offer for a flawed service? An examination of the nonlinear effects of compensation on satisfaction. Journal of Service Research, 18(1), 107-123.

Gelbrich, K., Gäthke, J., \& Grégoire, Y. (2016). How a firm's best versus normal customers react to compensation after a service failure. Journal of Business Research, 69, 4331-4339.

Haesevoets, T., Hiel, A.V., Folmer, C.R., \& Cremer, D.D. (2014). What money can't buy: The psychology of financial overcompensation. Journal of Economic Psychology, 42, 83-95.

Haesevoets, T., Hiel, A.V., Pandelaere, M., Bostyn, D.H., \& Cremer, D.D. (2017). How much compensation is too much? An investigation of the effectiveness of financial overcompensation as a means to enhance customer loyalty. Judgment and Decision Making, 12(2), 183-197.

Kenesei, Zs., \& Kolos, K. (2008). A hatékony panaszkezelés lehetőségei: kompenzáció és bocsánatkérés. Vezetéstudomány, 39(5), 27-39.

Kenesei, Zs., Kolos, K., \& Szilvai, Zs. (2017). A disztributív igazságosság fogalmának értelmezése a szolgáltatóvállalat nézőpontjából. Vezetéstudomány, 68(2), 30-39.

Kim, N., \& Ulgado, F.M. (2012). The effect of on - the - spot versus delayed compensation: The moderating role of failure severity. Journal of Services Marketing, 26(3), 158-167.

Malhotra, N.K. (2001). Marketingkutatás. Budapest, Magyarország: Müszaki Könyvkiadó.

Mannaa, M., \& Chaudhry, B. (2013): Role of justice in the complaint handling setting: Scenario-based experiment study. Academy of Contemporary Research Journal, 2(4), 131-151.

Mitev, A.Z. (2012). Grounded theory, a kvalitatív kutatás klasszikus mérföldköve. Vezetéstudomány, 63(2), 17-30.

Noone, B.M. (2012). Overcompensating for severe service failure: perceived fairness and effect on negative wordof-mouth intent. Journal of Services Marketing, 26(5), 342-351.

Noone, B.M., \& Lee, C.H. (2011). Hotel overbooking: The effect of overcompensation on customers' reactions to denied service. Journal of Hospitality \& Tourism Research, 35(3), 334-357.

Roschk, H., \& Gelbrich, K. (2014). Identifying appropriate compensation types for service failures: A metaanalytic and experimental analysis. Journal of Service Research, 17(2), 195-211.

Sirianni, N.J., Bitner, M.J., Brown, S.W., \& Mandel, N. (2013). Branded service encounters: Strategically aligning employee behavior with the brand positioning. Journal of Marketing, 77(6), 108-123.

Smith, A.K., Bolton, R.N., \& Wagner, J. (1999). A model of customer satisfaction with service encounters involving failure and recovery. Journal of Marketing Research, 36(3), 356-372.

Standop, D., \& Grunwald, G. (2009). How to solve product-harm crises in retailing? Empirical insights from service recovery and negative publicity research. International Journal of Retail \& Distribution Management, 37(11), 915-932.

Wirtz, J., \& Mattila, A. S. (2004). Consumer responses to compensation, speed of recovery and apology after a service failure. International Journal of Service Industry Management, 15(2), 150-166.

Zaubermann, G. (2003). The intertemporal dynamics of conusmer lock-in. The Journal of Consumer Research, 30, 405-419. 
CIKKEK, TANULMÁNYOK

\section{Mellékletek}

1. melléklet Tukey-teszt a kompenzációs formák és összegek hatásbeli különbözősége a szolgáltatással való elégedettségre

\begin{tabular}{|c|c|c|c|c|}
\hline \multicolumn{2}{|c|}{ Kompenzáció szintjei } & Átlag-eltérés & Std. hiba & Szign \\
\hline \multirow{2}{*}{$\begin{array}{c}\text { Nincs } \\
\text { kompenzáció }\end{array}$} & Készpénzalapú túlkompenzáció & $-0,97$ & 0,22 & 0,000 \\
\cline { 2 - 5 } & $\begin{array}{c}\text { Kuponjellegú t } \\
\text { túlkompenzáció }\end{array}$ & $-0,94$ & 0,25 & 0,001 \\
\hline \multirow{2}{*}{ Készpénzalapú túlkompenzáció } & Nincs kompenzáció & 0,97 & 0,22 & 0,000 \\
\cline { 2 - 5 } & $\begin{array}{c}\text { Kuponjellegú } \\
\text { túlkompenzáció }\end{array}$ & 0,03 & 0,25 & 0,990 \\
\hline \multirow{2}{*}{ Kuponjellegủ túlkompenzáció } & Nincs kompenzáció & 0,94 & 0,25 & 0,001 \\
\cline { 2 - 5 } & Készpénzalapú túlkompenzáció & $-0,03$ & 0,25 & 0,990 \\
\hline
\end{tabular}

Forrás: saját szerkesztés

2. melléklet Tukey-teszt a kompenzációs formák és összegek hatásbeli különbözősége a panaszkezelés észlelt igazságosságára az erőfeszítés függvényében

\begin{tabular}{|c|c|c|c|c|c|c|c|}
\hline Eröfeszítés mértéke & \multicolumn{3}{|c|}{ Nincs erőfeszítés } & \multicolumn{4}{c|}{ Van erőfeszítés } \\
\hline Kompenzáció szintjei & & Mean Difference & Std. Error & Sig. & Mean Difference & Std. Error & Sig. \\
\hline \multirow{2}{*}{ Nincs kompenzáció } & Készpénzalapú túlkompenzáció & $-0,51$ & 0,21 & 0,041 & $-1,10$ & 0,22 & 0,000 \\
\cline { 2 - 8 } & Kuponjellegú túlkompenzáció & $-0,19$ & 0,23 & 0,691 & $-0,85$ & 0,22 & 0,001 \\
\hline \multirow{2}{*}{$\begin{array}{c}\text { Készpénzalapú } \\
\text { túlkompenzáció }\end{array}$} & Nincs kompenzáció & 0,51 & 0,21 & 0,041 & 1,10 & 0,22 & 0,000 \\
\cline { 2 - 8 } & Kuponjellegú túlkompenzáció & 0,32 & 0,23 & 0,359 & 0,25 & 0,21 & 0,461 \\
\hline \multirow{2}{*}{$\begin{array}{c}\text { Kuponjellegú } \\
\text { túlkompenzáció }\end{array}$} & Nincs kompenzáció & 0,19 & 0,23 & 0,691 & 0,85 & 0,22 & 0,001 \\
\cline { 2 - 8 } & Készpénzalapú túlkompenzáció & $-0,32$ & 0,23 & 0,359 & $-0,25$ & 0,21 & 0,461 \\
\hline
\end{tabular}

Forrás: saját szerkesztés 